\title{
Kupała and Kolas through the Eyes of an Artist
}

\author{
BY
}

BARYS ZABORAǓ

Before tackling the theme of my paper I should like to say a few words about how I understand the principles of illustrating in general. Having illustrated not a few editions of children's literature, and of Byelorussian and foreign classics, I have come to understand that not all literature requires illustration and that not all illustration aids the reading of a literary work. Illustrations in a book can even be harmful by inculcating a wrong understanding of the literary work's nature and style. In each new encounter of an artist with a literary text he must be fully conscious of the purpose and function of the illustrations in that work. If, say, illustrations in a children's book do not arouse doubts, helping as they do the young reader to develop his imagination in discovering the world about him and thinking in images, the role of illustrations in serious literature and especially in poetry is completely different. It assumes a reader who is intellectually prepared. And when illustrations in literature of that kind contain a commentary on the contents and nothing more they come into conflict with the text, losing the struggle because in the course of the whole work the writer has considerably more possibilities to convey its idea and contents.

Thus, it seems to me that the book illustrator should not strive to help the writer or poet in his professional narration, taking on the role of prompter, but should rather offer his own concept of the literary work, his personal attitude to the reading of this material through the creative means at his disposal. To put it differently, the work of the artist in serious literature is, in my view, akin to that of the director in a theatre, for whom the basic literary material provides the basis for an independent creative process.

After making such rather lofty demands on the role of a book illustrator, it is difficult to turn to my own work, for the two items about which I shall speak were done over ten years ago and today show obvious deficiencies. But, absolutely different as they are, these two books* give some impression of my work in the field of book illustration.

When I was invited to illustrate the selection of Kupała's lyrics I accepted gladly, all the more so because, so far as I knew, there had never been such a large illustrated edition of Kupała's poetry in Byelorussia before.

Work with poetic material is, perhaps, the most complicated that an artist ever faces. Not all poetry lends itself to pictorial interpretation. For example, I cannot imagire illustrations to the poetry of Arthur Rimbaud, Chlebnikov, Pasternak, or Achmatova. But I can imagine illustrations to Villon, Burns, and Nekrasov. And I do not believe it is simply a matter of my personal response to poetry. There may well be objective reasons ior such a response.

* Janka Kupała, Vybranajc liryka, Minsk, 1967; Jakub Kołas, Symon-muzyka, Minsk, 1972. 
I would include Janka Kupała amongst the number of those poets whom it is possible to illustrate. His poetry is characterized by the concreteness of its imagery. His lyric hero is as real as life itself. He does not dissolve in a multitude of half-tones and shades. The poet fashions powerful realistic forms like a sculptor hewing his work from a block of granite. Janka Kupała's granite is the land and life of Byelorussia; it is real material, the joys and sorrows of which were well known to him. Being himself an integral part of this life and a great national bard, he responded to it with particular acuteness and pain, and precisely because, in my opinion, his poetry is as concrete as pain itself.

Beginning work on this book by selecting the technique and medium which would best correspond to my impression of Kupała's poetry, I settled on linocuts. This technique requires of the artist fine drawing and form. On the one hand the vivid realism and on the other the epic and publicistic qualities of Kupała's poetry faced me with the problem of choosing a compositional form for the illustrations which would correspond to these two strands.

Many variants were tried, but for a very long time I was satisfied with none of them. When I entered deeply into the highly complex living reality of Kupała's poetry my illustrations seemed too prosaically everyday. But when I became engrossed in the poems' symbolism Kupała's roots in real life became lost. It was necessary to find an artistic principle which would unite these two basic elements. Finally I arrived at the device of a monumentally constructed composition in which the main figure takes up practically the whole picture, with - for the hero's additional characterization a landscape or details of an interior. This approach allowed me to concentrate all my attention on the poet's main object - the lyrical hero. Such a principle seemed to offer the possibility of detailed modelling of the figure's psychological characteristics, at the same time raising him to a symbolic image.

Let us take as an example my illustration for Kupała's programme poem Mužyk with which the anthology opens. Most significant for me in deciding the image and composition was the poem's last line: 'Ja budu žyć — bo ja mužyk!'** In my view this line lies at the ideological heart not only of that poem but of the poet's entire philosophy of life and poetry. I wished to build this illustration in such a way that the plastic image of the peasant would look like a monument to him: the figure sitting on a scythe, his gaze turned directly towards the spectator, the clenched gesture of his right arm, with the left one lowered to the ground symbolizing the eternal link between peasant and land. Of course the artist's wishes are not necessarily realized in the way that he dreamt of, but such was the direction of his thought.

And what of the classical poem-hymn $A$ chto tam idzie? In the poem's five stanzas is painted such a grandiosely epic panorama that it is practically impossible to find an adequate pictorial image within the compass of a one-page illustration - a monumental fresco would be needed. But I was not prepared to forego illustrating this poem, and therefore settled on a compromise in the form of a composition consisting of a fragmentary relief. By this means I hoped to create the impression of an endless march going far beyond the bounds of a book illustration.

In illustrating Song of the Bellringer, an allegorical poem symbolizing the poet and his calling, I used only landscape: the Byelorussian villages

\footnotetext{
* 'I will live - for I am a peasant'.
} 
above which the belltower rises. Its dimensions are not really great, but in my conception it should grow into a symbol with the two bare tree trunks on either side making a kind of dramatic gateway - the entrance to this space.

It is a very thankless task for an artist to analyze his own work, and for that reason I confine myself to the above three poems, the more so because the other verses are treated according to the same principle I had chosen. Naturally, individual nuances occurred in each case. Depending on the composition of the verse it was necessary to bring out its epic basis, or its lifelike realism, or again its symbolism. Thus in my illustration to the poem Nad katyskaj, I wanted to raise to a symbolic level what I saw as the exceptionally lyrical image of mother and son. To this end I chose artistic means which were intended to distantly echo the canonic portraits of Madonna and child. And so on.

A few years later the 'Biełaruś' publishing house decided to produce a presentation edition of Jakub Kołas's poem Symon-muzyka, and, knowing this poem from childhood, I gladly set about providing illustrations. The more I studied the poem the more I became convinced of its exceptional qualities. not only in the context of Kołas's work but of all Byelorussian poetry. In its endlessly rich images, its language and use of folklore, its verse forms and metre, this poem not only incorporated all the poetic achievements of Kołas's predecessors, but also enriched future Byelorussian poetic literature by its compositional discoveries. It is a striking fact that nowhere in the poem is there any place where the form of the verse, metre, rhythmic pattern, language are simply an artistic device. Each verse, each song with its rich poetic modulations is directed towards creating the spiritual atmosphere in which the hero lives. Each stanza of the poem changes the lyrical intonation: to a narrative mode or to lofty epic, to recitative, to metaphoric and symbolic narration, and to dialogue, each more deeply revealing the work's fundamental idea, namely the eternal and irreconcilable conflict between the state and authority on the one hand, and the artist on the other.

There exist works of literature which, regardless of when they were written and of their national and geographical provenance, carry thoughts which are always actual and alive, emotive and dear to people of all periods. It is to this category of works that in my opinion Kołas's Symon-muzyka belongs. On the basis of material which is highly national the poet brings forth general philosophical concepts which go far beyond mere individual instances, and which in the poem become allegorical symbols. In the conflict between the creative artist and his environment the poet is entirely on the side of the former. Kołas paints the image of Symon with endless love. He is presented as inseparably linked with nature. All the pictures of nature in the poem, personifying the life and surroundings of the artist, are drawn by Kolas with unusual poetic insight and warmth. Symon the artist is spiritually fused with nature. He listens to the discourse of butterflies and understands birds' laughter, he feels the pain of a picked flower and the sigh of the ploughed earth, he responds to the flight of the clouds and to the eternal life of fire:

O, kraj rodny, kraj pryhožy!

Miły kut maich dziadoŭ!

Śto milej u: śviecie Božym

Hetych śvietrych bierahoŭ.*

* 'O my native land, my beauliful land! / Dear corner of my ancestors! / What is dearer in God's earth / Than these bright shores.' 
And so it is!

Symon's conflict with life begins in his own home:

Biedny chłopčyk byǔ zahnany, U bačkoŭ nialuby syn,

Nie taki, jak usie dzieci,

Niejki vyradak, dziǔny,

Nios vinu za ǔsio na śviecie,

Vinavaty biez viny.*

Could not the last two lines serve as an epigraph to the fate of all true artists? Symon is exploited by everyone, each seeking only profit for himself tramp, innkeeper, and prince alike. No-one even tries to understand the artist's soul.

Two of Symon's meetings in the poem are coloured by love and tenderness towards the hero: the first with grandfather Kuryła, the second with Hanna. But I understand both these meetings not as elements in Symon's biography but as allegorical symbols: Kuryła represents the transmission of the national folk heritage without which an artist cannot exist; Hanna is a symbol of pure, ideal love, an image of eternal beauty and the goal of artistic creation. Thus, the creative personality is firmly based on three elements: nature, that is life, the cultural heritage, and an ideal of love. The enemy forces, on the other hand, are society and power.

Such were my thoughts as I embarked on the illustrations. Now, ten years after the book's appearance, I can see many mistakes. The greatest is that I allowed myself too many purely decorative devices to the detriment of the pictures' essence. But at the same time this work remains something of a milestone in my work as a book illustrator. The book was conceived as a series of coloured pictures on a small-format block recalling the white and blue money-box 'Biełaja Ruś'. Perhaps this association was very strained and abstract, but that is how I conceived it. My desire was that the book should look both attractive and worth cherishing carefully. I feel that the pictures on a large white background and the narrow strip of the text have given the book a radiant and elegant appearance.

The question of colour here was for me not simply a pictorial problem. I wanted to distribute it in the text in such a way as to create the poem's emotional image by means of colour alone; hence the bright colour range of each picture. From the first one, green - the most typical colour of the Byelorussian countryside - and with a gradual development through the red and brown of the prince's castle - symbolic of power and force - towering over the poor peasant huts, and finally, in the last picture, to the azure of the sky, with the major chord of the finale indicating hope.

I see no sense in dwelling on each illustration. My purpose has been to discuss an artist's creative process as it relates to the reading of literature, and the realization of his aims by pictorial means. Certainly my account is incomplete. I have omitted everything connected with the process of technical execution and the difficulties that arise from it, as well as the obstacles created by publishers and editors which, incidentally, can be greater than purely creative problems. In fact, I encountered a great number of such problems with these two books, but that could form the subject of another lecture...

\footnotetext{
* 'The poor boy was oppressed / The unloved son of his parents... / Not like all other children, / Some strange monster, / he bore the blame for everything on earth, / Blamed yet without blame.'
} 